\title{
Hemangiopericytic Neoplasm
}

National Cancer Institute

\section{Source}

National Cancer Institute. Hemangiopericytic Neoplasm. NCI Thesaurus. Code C7076.

A term that refers to vascular neoplasms with a prominent hemang iopericytic growth pattern. 